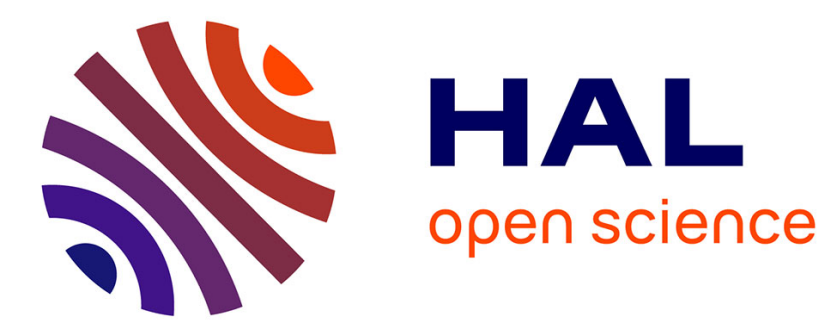

\title{
Extraction and characterization of pectic substances from pulp of grape berries
}

\author{
L. Saulnier, J.F. Thibault
}

\section{To cite this version:}

L. Saulnier, J.F. Thibault. Extraction and characterization of pectic substances from pulp of grape berries. Carbohydrate Polymers, 1987, 7, pp.329-343. hal-02721309

\section{HAL Id: hal-02721309 \\ https://hal.inrae.fr/hal-02721309}

Submitted on 1 Jun 2020

HAL is a multi-disciplinary open access archive for the deposit and dissemination of scientific research documents, whether they are published or not. The documents may come from teaching and research institutions in France or abroad, or from public or private research centers.
L'archive ouverte pluridisciplinaire HAL, est destinée au dépôt et à la diffusion de documents scientifiques de niveau recherche, publiés ou non, émanant des établissements d'enseignement et de recherche français ou étrangers, des laboratoires publics ou privés. 


\title{
Extraction and Characterization of Pectic Substances from Pulp of Grape Berries
}

\author{
Luc Saulnier* and Jean-François Thibault \\ Institut National de la Recherche Agronomique, Centre de Recherches \\ Agro-Alimentaires, Laboratoire de Biochimie et Technologie des Glucides, \\ 44072 Nantes Cedex, France
}

(Received 29 May 1986; accepted 24 January 1987)

\section{SUMMARY}

Pectic substances were successively extracted from the alcohol-insoluble residue (AIR) of the pulp of grape berries, by water (WSP), oxalate (OXP), hot dilute $\mathrm{HCl}(\mathrm{HP})$ and cold dilute NaOH (OHP). Pectins (WSP, OXP, $H P)$ were purified by ion-exchange chromatography (DEAE-Sephacel) or precipitation with cupric ions (OHP). Total pectic substances represent $20 \cdot 8 \%(w / w)$ of the AIR, WSP and HP being the main components $6 \%$ and $12 \%$ of the AIR, respectively). An alternative to oxalate extraction of the water-insoluble pectin was extraction with $\mathrm{NaCl}$ solutions of increasing concentrations, which had released small amounts of pectins. Each of the fractions contained mainly galacturonic acid, arabinose and galactose, lower amounts of rhamnose and xylose, and minor amounts of glucose and mannose. Ion-exchange chromatography was performed on $D E A E-S e p h a c e l, M_{w}$ distribution was checked by gel permeation on Sepharose $C L-2 B$, and $M_{v}$ was determined as well as degrees of methylesterification $(D M)$, acetylation $(D A)$, and protein content.

\section{INTRODUCTION}

Pectins are heteropolysaccharides built of a rhamnogalacturonan backbone, in which sequences of $(1 \rightarrow 4)$-linked $\alpha$-D-galacturonic acid residues are interrupted by $\alpha$-L-rhamnosyl residues carrying side-chains composed mainly of arabinose and galactose (Aspinall, 1980; Dey \&

\footnotetext{
* Present address: INRA, Institut des Produits de la Vigne, Laboratoire des Polymeres et des Techniques Physico-Chimiques, 9 Place Viala, 34060 Montpellier Cedex, France.

Carbohydrate Polymers 0144-8617/87/\$03.50- C Elsevier Applied Science 
Brinson, 1984). They are the major components of the middle lamella of plant tissues, especially those of fruits. Pectins from various plant species have some common structural trends (Albersheim, 1975), although differences exist in their composition and structure especially during the maturation (Pilnik \& Voragen, 1970; Knee \& Bartley, 1981). Because of their function in the cell wall, pectins play a very important role in food processing (Pilnik \& Rombouts, 1985). In winemaking pectins are involved in juice extraction processes and subsequent operations such as clarification and filtration. Up to now, studies on grape pectic substances have concentrated on changes during maturation (Robertson et al., 1980; Mourgues, 1981). Pectins were also studied in musts and wines (Usseglio-Tomasset, 1978; Mourgues, 1979), but no data are available relating to general characterization in grape berries. The present paper deals with sequential extractions of pectic substances from an alcoholinsoluble residue (AIR) of grape berries, with water, potassium oxalate, hot $\mathrm{HCl}$ and cold $\mathrm{NaOH}$, or with $\mathrm{NaCl}$ solutions of increasing ionic strength. The aim of this preliminary study is to characterize the extracted pectic substances in order to perform further structural investigation.

\section{METHODS}

\section{Plant material}

Ripe grapes (Vitis vinifera, variety Red Carignan) were picked at the Domaine Experimental de Pech Rouge (I.N.R.A., 11430 Gruissan, France) in October 1984. The berries were frozen and stored at $-20^{\circ} \mathrm{C}$ after harvesting.

\section{Preparation of alcohol-insoluble residue (AIR)}

Preparation of AIR followed the methods described by Mourgues, (1981) and Barbier \& Thibault (1982). The frozen berries were deseeded and the skins were hand separated from the pulps. The pulp was immersed for $10 \mathrm{~min}$ in boiling $95 \%$ ethanol (ratio 1:5 w/w) under magnetic stirring, ground for $3 \mathrm{~min}$ with a polytron mixer, then the mixture was centrifuged for $15 \mathrm{~min}(3000 \mathrm{~g})$. The insoluble residue (AIR) was recovered and washed with $95 \%$ ethanol until the eluate became colourless. The AIR was dried $\left(24 \mathrm{~h}, 40^{\circ} \mathrm{C}\right)$ under vacuum and hand ground in a mortar. 


\section{Extraction of pectic substances}

The methods described by Pilnik \& Voragen (1970), Barbier \& Thibault (1982) and Rombouts \& Thibault (1986) were followed. Pectic substances were sequentially extracted as follows:

Sequential extraction I: AIR $(4 \mathrm{~g})$ was dispersed at room temperature $\left(20^{\circ} \mathrm{C}\right)$ by magnetic stirring in $250 \mathrm{ml}$ of distilled water for $30 \mathrm{~min}$, the slurry was centrifuged at $3000 \mathrm{~g}\left(20^{\circ} \mathrm{C}\right)$ and the supernatant was collected (WSP); the entire procedure was repeated three times. The residue from the water extraction was similarly treated with $1 \%$ potassium oxalate $(\mathrm{pH}$ $\left.4.5,20^{\circ} \mathrm{C}\right), 0.05 \mathrm{~N} \mathrm{HCl}\left(80^{\circ} \mathrm{C}\right)$ and $0.05 \mathrm{~N} \mathrm{NaOH}\left(4^{\circ} \mathrm{C}\right)$, successively. Supernatants from $\mathrm{HCl}$ and $\mathrm{NaOH}$ extraction were adjusted to $\mathrm{pH} 4 \cdot 5$.

Sequential extraction II: AIR (4 g) was extracted with water as described above. The residue from water extraction was submitted to $\mathrm{NaCl}$ solutions of increasing ionic strength, $0.16 \mathrm{M}, 0.5 \mathrm{M}$, and $1 \mathrm{M}$ using the same conditions as described for water extraction $\left(20^{\circ} \mathrm{C}\right)$. The $\mathrm{pH}$ of the salt solutions was adjusted to $4 \cdot 5$.

All the fractions were concentrated under vacuum below $40^{\circ} \mathrm{C}$, extensively dialysed against distilled water, filtered on a $3.0 \mu \mathrm{m}$ Millipore sieve and finally precipitated by addition of 4 vol. of $95 \%$ ethanol. The settled precipitates were dried by solvent exchange through absolute ethanol, acetone and ether and finally under vacuum at $40^{\circ} \mathrm{C}$ for $24 \mathrm{~h}$.

\section{Purification of pectins}

Aqueous solutions $(40 \mathrm{ml})$ of pectic substances (WSP, OXP, HP) $(400$ $\mathrm{mg}$ ) were loaded on a DEAE-Sephacel column $(3.2 \mathrm{~cm} \times 150 \mathrm{~cm})$, and the gel was washed by $250 \mathrm{ml}$ of $0.01 \mathrm{M}$ sodium acetate buffer, $\mathrm{pH} 4.8$, $50 \mathrm{ml} \mathrm{h}{ }^{-1}$. The bound material was eluted with $250 \mathrm{ml}$ of $1 \mathrm{M}$ sodium acetate buffer, $\mathrm{pH} 4.8$. Fractions $(10 \mathrm{ml})$ were collected and assayed for their galacturonic acid and neutral sugar content. Then the purified material was dialysed and isolated as described above. OHP was purified by precipitation with cupric ions as described by Michel et al. (1981) (OHP). Pectins obtained by fractionation with $\mathrm{NaCl}$ were studied without purification.

\section{Analyses}

Galacturonic acid (expressed as the anhydro form, AGA) and total neutral sugars (expressed as anhydro-arabinose) were automatically determined by the $m$-phenylphenol (Blumenkrantz \& Asboe-Hansen, 
1973; Thibault, 1979) and the orcinol (Tollier \& Robin, 1979) method, respectively (responses were corrected for mutual interferences). Methanol was determined by the method of Wood \& Siddiqui (1971) and acetyl content was analysed as described elsewhere (Jouany, 1982; Rombouts \& Thibault, 1986). Degrees of methylesterification (DM) and of acetylation (DA) were expressed as the molar ratio relative to 100 moles of galacturonic acid. Protein content was estimated by the method of Lowry et al. (1951), as described by Potty (1969). Individual monosaccharides were released by TFA $\left(2 \mathrm{M}, 1.25 \mathrm{~h}, 120^{\circ} \mathrm{C}\right)$ and sulphuric acid $(2$ $\left.\mathrm{N}, 1 \cdot 5 \mathrm{~h}, 100^{\circ} \mathrm{C}\right)$ hydrolysis of pectins and analysed by g.l.c. as their alditol acetate (Selvendran et al., 1979). Galacturonic acid and neutral sugar contents of AIR and residue were determined according to the methods of Ahmed et al. (1977) and Saeman et al. (1954) respectively.

\section{Viscosity measurements}

Intrinsic viscosities values were obtained at $25^{\circ} \mathrm{C}$ with an automatic FICA viscosmeter (solvent flow time 270.9 s). Samples of pectin $(5 \mathrm{mg}$ $\mathrm{ml}^{-1}$ ) were dissolved in $0.155 \mathrm{M} \mathrm{NaCl}$ soln. The viscosity-average molecular weight $\left(M_{\mathrm{v}}\right)$ was calculated according to the coefficient determined by Owens et al. (1946).

\section{Gel permeation chromatography}

Aqueous solutions $(1 \mathrm{ml})$ of pectin $(5 \mathrm{mg})$ were injected on to a Sepharose $2 \mathrm{~B}-\mathrm{CL}$ column $(86 \mathrm{~cm} \times 2.6 \mathrm{~cm})$, and elution was made with $0.1 \mathrm{M}$ sodium acetate buffer, $\mathrm{pH} 4 \cdot 0$, at $20 \mathrm{ml} \mathrm{h}^{-1}$. Fractions were collected and analysed for their galacturonic acid and neutral sugar content as described above. Results were expressed as a function of $K_{\mathrm{av}}=\left(V_{\mathrm{e}}-V_{0}\right) /$ $\left(V_{\mathrm{t}}-V_{0}\right)$, where $V_{\mathrm{e}}, V_{0}$ and $V_{\mathrm{t}}$ are the elution volume of the fraction, the void volume of the column and the total volume of the column, respectively.

\section{Ion-exchange chromatography}

Aqueous solutions $(1 \mathrm{ml})$ of pectins $(5 \mathrm{mg})$ were loaded on to a DEAESephacel column $(7.5 \mathrm{~cm} \times 1.6 \mathrm{~cm})$ and the gel was washed with $50 \mathrm{ml}$ of $0.05 \mathrm{M}$ sodium acetate buffer, $\mathrm{pH} 4.8$, at $40 \mathrm{ml} \mathrm{h}^{-1}$. The bound material was eluted using a linear gradient $(90 \mathrm{ml}, \mathrm{pH} 4.8,0.05 \mathrm{M}-0.08 \mathrm{M}$ or 0.05 M-1 M) of sodium acetate buffer. Fractions $(4 \mathrm{ml})$ were collected and analysed as above. 


\section{RESULTS AND DISCUSSION}

\section{Alcohol-insoluble residue (AIR)}

Preparation of AIR induces coprecipitation of cytoplasmic proteins, polyphenols and salts on cell-wall material (Selvendran, 1975). Grape berries are very rich in organic acids, mainly tartaric and malic acids (Peynaud \& Ribereau-Gayon, 1971). These have been found in large amounts $(65 \%(\mathrm{w} / \mathrm{w})$ determined after extensive dialysis) in the potassium form in the AIR. Subsequently results were corrected for salt present in the AIR. The sugar content and composition of the AIR are reported in Table 1 . Galacturonic acid and neutral sugars represent only $33.7 \%$ in weight of the AIR. The yield is $0.54 \%$ (fresh wt. basis) of the pulp $(71 \%(w / w)$ of the fresh berry).

TABLE 1

Sugar Composition (\% dry wt.) of AIR and Residue of Extraction. ${ }^{a}$

\begin{tabular}{lrl}
\hline & AIR & Residue \\
\hline AGA & $11 \cdot 6$ & $2 \cdot 1(8)$ \\
Rha & 0.7 & $0.4(27)$ \\
Ara & $1 \cdot 7$ & $1.9(53)$ \\
Xyl & $2 \cdot 3$ & $6 \cdot 2(129)$ \\
Man & $1 \cdot 0$ & $2 \cdot 0(96)$ \\
Gal & $2 \cdot 2$ & $1.7(37)$ \\
Glu & $15 \cdot 9$ & $30 \cdot 6(93)$ \\
\hline
\end{tabular}

${ }^{a}$ Values in parentheses are recovery in wt. from AIR (i.e. \% dry weight of AIR sugars retained in residue).

\section{Sequential extraction I}

Four pectic fractions were recovered after successive extraction with cold water (water-soluble pectin, WSP), cold potassium oxalate (oxalatesoluble pectin, $\mathrm{OXP}$ ), hot $\mathrm{HCl}$ (acid-soluble pectin, $\mathrm{HP}$ ) and cold $\mathrm{NaOH}$ (alkali-soluble pectin, OHP). Yields and composition are reported in Table 2 . The recovery including the final residue was $96.7 \%$ (w/w) of the starting AIR. The major fractions were WSP and HP, minor amounts of pectins being extracted with oxalate or alkali. This sequential extraction apparently released the major part, if not all, of pectic substances since only minute amounts of uronic acids are still present in the residue after extraction. Rhamnose, arabinose and galactose are widely extracted too, 
TABLE 2

Yield (\% wt. of AIR) and Composition (\% dry wt.) of Crude Pectins and Final Residue

\begin{tabular}{lccc}
\hline Extraction I & Yield & AGA & Neutral sugars $^{a}$ \\
\hline WSP & $10 \cdot 8(22)$ & $50 \cdot 0$ & $15 \cdot 0$ \\
OXP & $3 \cdot 7(7 \cdot 5)$ & $48 \cdot 8$ & $11 \cdot 2$ \\
HP & $31 \cdot 4(64 \cdot 5)$ & $30 \cdot 7$ & $9 \cdot 5$ \\
OHP & $2 \cdot 8(6)$ & $36 \cdot 6$ & $15 \cdot 0$ \\
Residue $^{c}$ & $48 \cdot 0$ & $2 \cdot 1$ & $42 \cdot 8$ \\
\hline Extraction II & & & \\
\hline WSP & $10 \cdot 8$ & $50 \cdot 0$ & $15 \cdot 0$ \\
SP0.16 & $1 \cdot 0$ & $40 \cdot 0$ & $12 \cdot 2$ \\
SP0.5 & $1 \cdot 0$ & $44 \cdot 4$ & $6 \cdot 6$ \\
SP1 & $0 \cdot 3$ & nd & \\
\hline
\end{tabular}

${ }^{a}$ AGA was determined by the $m$-phenylphenol method, and expressed as the anhydro form.

${ }^{b}$ Neutral sugars were determined by the orcinol method, and expressed as anhydroarabinose.

${ }^{c}$ Residue composition was determined according to Saeman et al. (1954), Ahmed and Labavitch (1977).

${ }^{d}$ nd: not determined.

while glucose, xylose and mannose are slightly affected by the extraction process (sce Table 1). The pectic content of grape is low $(0 \cdot 26 \%(\mathrm{w} / \mathrm{w})$ of the fresh material), as compared with other fruits (Kabawata, 1977), but this value is in good agreement with previously reported results $(0.12 \%$ to $0.27 \%$ ) (Kabawata, 1977; Vidal-Valverde et al., 1982; Mourgues, 1983). These crude pectins were submitted to ion-exchange chromatography on DEAE-Sephacel (yields $75-80 \%$ in galacturonic acid) and the results are shown in Fig. 1. Some material is not bound on the column and represents $13 \%, 2 \%$ and $6 \%(\mathrm{w} / \mathrm{w})$ of the initial WSP, OXP and HP, respectively. Most of the injected material is bound, and is mainly composed of galacturonic acid associated with neutral sugar which are coeluted by a linear acetate buffer gradient $(0.05 \mathrm{M}$ to $1 \mathrm{M})$. WSP exhibit a sharp peak eluted with $0.5 \mathrm{~m}$ acetate buffer; in contrast, $\mathrm{OXP}$ and HP exhibit different elution patterns since two peaks not fully resolved are eluted with $0.4 \mathrm{M}$ and $0.7 \mathrm{M}$ acetate buffer, and the fraction eluted at the higher ionic strength has a lower galacturonic acid/neutral sugar ratio. This elution pattern suggests that OXP and HP consist of two components as shown by their galacturonic acid/neutral sugar ratio. OHP which are de-esterified during extraction are largely irreversibly 


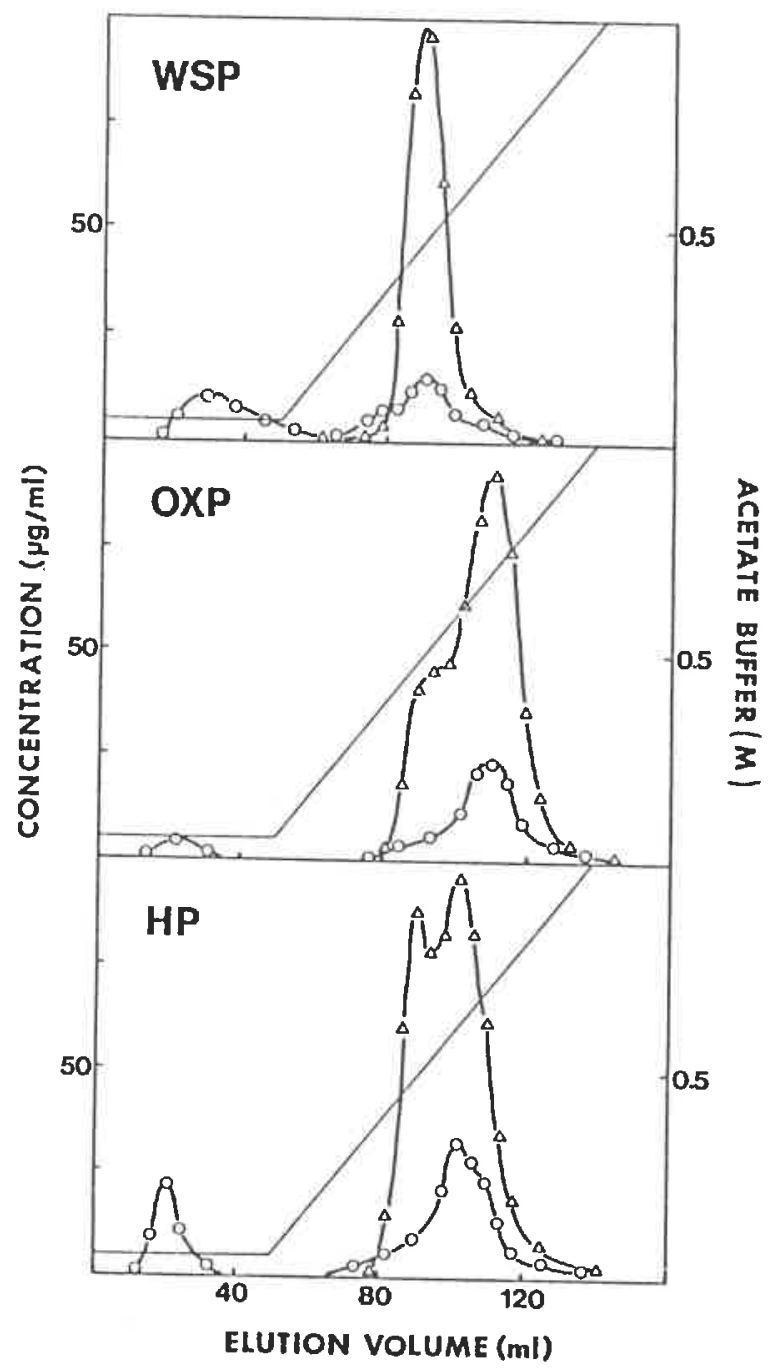

Fig. 1. Ion-exchange chromatography of crude pectic substances from pulp of grape berries on DEAE-Sephacel. WSP, water-soluble pectins; OXP, oxalate-soluble pectins; $\mathrm{HP}$, acid-soluble pectins. $-\triangle-$ anhydrogalacturonic acid, $-\mathrm{O}-$ neutral sugars determined by $m$-phenylphenol and orcinol method, respectively. Chromatograms were recalculated for $1.4 \mathrm{mg}$ (WSP), $2.3 \mathrm{mg}(\mathrm{OXP})$ and $2.7 \mathrm{mg}$ (HP) of injected AGA.

bound to the gel ( $9 \%$ of total OHP galacturonic acid content was recovered, material not bound represent $4 \%(w / w)$ of the initial OHP).

For further characterization, substantial amounts of WSP, OXP and HP were purified by semi-preparative ion-exchange chromatography on DEAE-Sephacel. The yield in galacturonic acid was in the range $75-80 \%$, attempts to release more material from the column by elution with $0.01 \mathrm{~N} \mathrm{NaOH}$, as described by De Vries et al. (1981) were not successful. OHP were purified by precipitation with cupric ions. The purified and the crude pectins behave similarly on DEAE-Sephacel, with smaller amounts of ballast $5 \%, 0.4 \%$ and $2 \%$ for the purified WSP, 
OXP and HP, respectively). This purification leads to an appreciable increase in the galacturonic acid content of the pectins (see Table 3), WSP and HP still being the major components, $31.8 \%$ and $57.7 \%$ of total purified pectins, whereas OXP and OHP represent only $6.7 \%$ and $3 \cdot 8 \%$, repectively.

TABLE 3

Composition (\% dry wt.) of Purified WSP, OXP, HP, OHP and of Crude SP0 16 , SP0.5 and Viscosity Average $M_{\mathrm{w}}\left(M_{\mathrm{v}}\right)$

\begin{tabular}{|c|c|c|c|c|c|c|}
\hline & $W S P$ & $O X P$ & $H P$ & $O H P$ & $S P O \cdot 16$ & $S P O \cdot 5$ \\
\hline $\begin{array}{l}\text { Galacturonic } \\
\operatorname{acid}^{a}\end{array}$ & $63 \cdot 3$ & $63 \cdot 3$ & $53 \cdot 3$ & $54 \cdot 4$ & $40 \cdot 0$ & $44 \cdot 5$ \\
\hline Rha + Fuc $^{c}$ & $3 \cdot 0$ & $5 \cdot 3$ & $5 \cdot 8$ & $5 \cdot 6$ & $4 \cdot 0$ & $3 \cdot 3$ \\
\hline Ara & $10 \cdot 4$ & $7 \cdot 1$ & $7 \cdot 7$ & $3 \cdot 5$ & $8 \cdot 7$ & $5 \cdot 1$ \\
\hline Xyl & $2 \cdot 1$ & $2 \cdot 2$ & $0 \cdot 6$ & $2 \cdot 4$ & $2 \cdot 1$ & $1 \cdot 6$ \\
\hline Man & $0 \cdot 1$ & $0 \cdot 1$ & $0 \cdot 1$ & $0 \cdot 2$ & 0.9 & $0 \cdot 5$ \\
\hline $\mathrm{Gal}$ & $12 \cdot 2$ & $4 \cdot 8$ & $4 \cdot 4$ & $5 \cdot 5$ & $6 \cdot 1$ & $3 \cdot 4$ \\
\hline Glu & $0 \cdot 6$ & $0 \cdot 3$ & $0 \cdot 6$ & $0 \cdot 8$ & $1 \cdot 3$ & $0 \cdot 8$ \\
\hline Methanol $^{c}$ & $8 \cdot 5(77)$ & $7 \cdot 6(69)$ & $6.4(68)$ & $0 \cdot 3(4)$ & $3 \cdot 8(54)$ & $3 \cdot 5(50)$ \\
\hline Acetic acid ${ }^{d}$ & $0.4(2)$ & $0.5(2 \cdot 3)$ & $1(5 \cdot 1)$ & $0 \cdot 4(2 \cdot 3)$ & $\mathrm{nd}^{e}$ & nd \\
\hline Protein & $2 \cdot 5$ & 2 & $10 \cdot 4$ & $9 \cdot 1$ & nd & nd \\
\hline$[\eta]\left(\mathrm{ml} \mathrm{g}^{-1}\right)$ & 224 & 212 & 240 & 200 & nd & 343 \\
\hline Huggins coef. & 0.59 & $0 \cdot 60$ & 0.52 & 0.64 & nd & $0 \cdot 04$ \\
\hline$M_{\mathrm{v}}$ & 42650 & 40950 & 44900 & 39200 & nd & 52600 \\
\hline
\end{tabular}

${ }^{a}$ Galacturonic acid determined by $m$-phenylphenol method, results are expressed as the anhydro form.

${ }^{b}$ Neutral sugars determined by g.l.c. as alditol acetate, after TFA hydrolysis of pectin, results are expressed as the anhydro form.

${ }^{c}$ Values in parentheses are degrees of methylation.

${ }^{d}$ Values in parentheses are degrees of acetylation.

${ }^{e}$ nd, not determined.

The chemical composition of the purified pectins is shown in Table 3 . Both WSP and OXP have galacturonic acid content of $63.3 \%(\mathrm{w} / \mathrm{w})$ which is higher than those of HP and OHP $(53.3 \%$ and $54.4 \%$, respectively). The four fractions contain the same neutral sugars, mainly galactose, arabinose and rhamnose, with minor amounts of xylose, glucose and mannose. Differences between the samples can be seen in the relative amounts of each sugar and total neutral sugar content (see Table 3 ). 
WSP have a higher neutral sugar content $(28.5 \%(w / w))$ than OXP, HP and $\operatorname{OHP}(20 \%, 19 \cdot 5 \%$ and $18.2 \%$, respectively). Arabinose and galactose are found in equivalent molar amounts in WSP and OHP whereas OXP and HP have higher amounts of arabinose. Rhamnose and fucose were not separated under our chromatographic conditions, but fucose was always found as a minor constituent. We have observed that the amounts of rhamnose released by sulphuric acid $\left(2 \mathrm{~N}, 1.5 \mathrm{~h}, 100^{\circ} \mathrm{C}\right)$ hydrolysis were always lower than by TFA $\left(2 \mathrm{M}, 1.25 \mathrm{~h}, 120^{\circ} \mathrm{C}\right)$ hydrolysis while no differences were detected with other sugars. Furthermore rhamnose, which is known as a branching point for side-chains (Dey \& Brinson, 1984), was more abundant in grape pectins than in other fruits such as cherry (Barbier \& Thibault, 1982), apple (De Vries et al., 1981) or citrus (De Vries et al., 1984). The lowest rhamnose content is found in the WSP which contains the highest amount of neutral sugars, suggesting a higher degree of polymerization of the side-chains. The presence of protein is detected in the purified pectins (see Table 3) as reported in previous work (Barbier \& Thibault, 1982; Stevens \& Selvendran, 1984; Rombouts \& Thibault, 1986). Acetyl groups are present in the grape pectins in relatively low amounts compared with apricots (Souty et al., 1981) or sugar-beet (Rombouts \& Thibault, 1986), but the degree of methylesterification (DM) is high $(77 \%$ to $68 \%)$, with the exception of OHP. The low DM of the latter is due to the extraction method used. OXP which are thought to be bonded through calcium ions in the cell wall, have a surprisingly high DM value $(69 \%)$. Similar values have been previously reported in oxalate-soluble pectins from other fruits (De Vries et al., 1981; Souty et al., 1981; Barbier \& Thibault, 1982; Rombouts \& Thibault, 1986) but remained unexplained. This is discussed further (below).

All pectins are highly polydisperse as shown by their elution pattern on Sepharose 2B-CL (yields $90 \%$ to $100 \%$ in galacturonic acid). WSP and OXP on the one hand, HP and OHP on the other hand, behave similarly on this gel (see Fig. 2). Both WSP and OXP contain low $M_{\mathrm{w}}$ material ( $K_{\mathrm{av}} 0.75$ and 0.8 for WSP and OXP, respectively) but OXP shows a relatively constant galacturonic acid/neutral sugar ratio along the profile, while WSP exhibit high galacturonic acid/neutral sugar ratio at low $K_{\mathrm{av}}$ and low galacturonic acid/neutral sugar ratio at high $K_{\mathrm{av}}$, which means that two different populations are eluted. HP and OHP are eluted in two acidic populations of low $\left(K_{\mathrm{av}} 0 \cdot 8\right)$ and high $\left(K_{\mathrm{av}} 0 \cdot 5\right) M_{\mathrm{w}}$, with only slight variations in galacturonic acid/neutral sugar ratio. Some of the HP is excluded from the gel.

Molecular weights obtained from intrinsic viscosities (Table 3) were similar for all the pectins $\left(M_{\mathrm{v}} \approx 40000\right)$, and differences obtained 


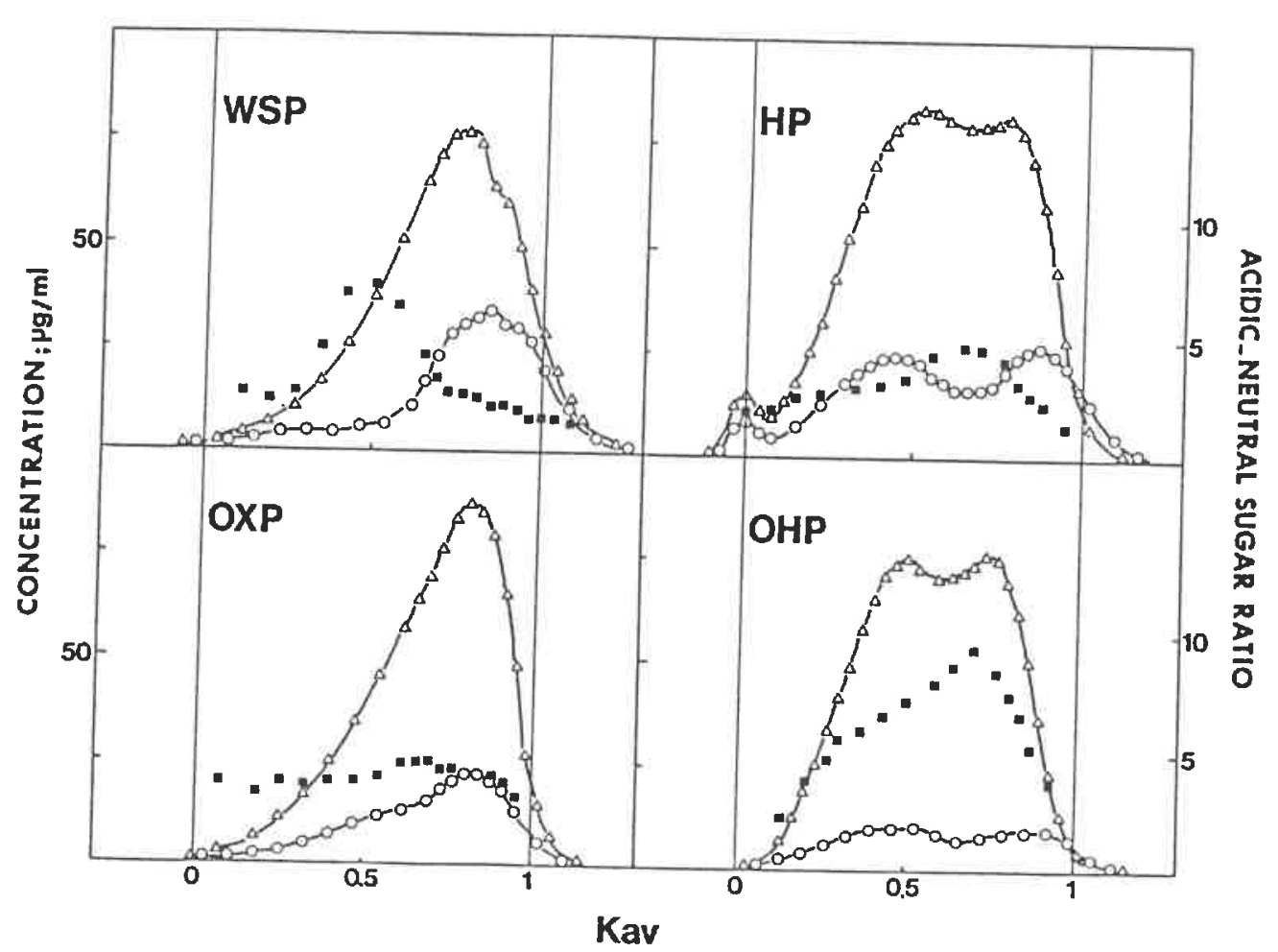

Fig. 2. Gel-permeation chromatography of purified pectic substances from pulp of grape berries on Sepharose 2B-CL WSP, water-soluble pectins; OXP, oxalate-soluble pectins; HP, acid-soluble pectins; OHP, alkali-soluble pectins. $-\Delta-$ anhydrogalacturonic acid, - - neutral sugars determined by $m$-phenylphenol and orcinol method respectively. - - acidic/neutral sugars ratio. Chromatograms were recalculated for 4 $\mathrm{mg}$ (WSP), $4.5 \mathrm{mg}$ (OXP), $6.5 \mathrm{mg}$ (HP) and $5.2 \mathrm{mg}$ (OHP) of injected AGA.

between HP and WSP $\left(M_{\mathrm{v}}=42650\right.$ and 44900 for WSP and HP, respectively) are much smaller than those expected from the Sepharose 2B-CL chromatograms. These $M_{v}$ values are smaller than those of cherry (Barbier \& Thibault, 1982) or apple (Rouau \& Thibault, 1984) but in good agreement with those found for pectins extracted from grape pomace (Mourgues \& Courtoisier, 1983).

\section{Sequential extraction II}

The AIR was strongly contaminated with malate and tartrate which are calcium chelating agents. It is therefore likely that calcium-bonded pectins, which are thought to be present in cell wall (Jarvis, 1984), have been removed during water extraction. However, subsequent treatment of the AIR with oxalate always removed amounts of pectins which remained constant whatever the maturity stage (Mourgues, 1981, 1983). The high DM value obtained for OXP was not consistant with the 
sequential extraction used, which is intended to remove the three main categories of pectic substances: high methoxyl pectin (water soluble), low methoxyl pectin (extracted by calcium ion-binding agents) and protopectin (hot $\mathrm{HCl}$ and/or cold $\mathrm{NaOH}$ soluble) (Pilnik \& Voragen, 1970). Oxalate acts as calcium chelator, but its presence also increases the ionic strength of the solution which under our conditions is equal to $0 \cdot 16$. Therefore we have carried out a sequential extraction with aqueous solutions of increasing ionic strength.

After extraction with water, the residue was also treated with $\mathrm{NaCl}$ solutions. Three pectic fractions were recovered: $0 \cdot 16 \mathrm{M} \mathrm{NaCl}$-soluble (SP0.16), 0.5 $\mathrm{m} \mathrm{NaCl}$-soluble (SP0.5) and $1 \mathrm{~m} \mathrm{NaCl}$-soluble (SP1). Yields and composition are reported in Table 2 . The $0.16 \mathrm{M} \mathrm{NaCl}$ solution extracts $1 \%(\mathrm{w} / \mathrm{w})$ of AIR while oxalate extracted $3.7 \%$, and the total yield from all the $\mathrm{NaCl}$ extractions is only $2 \cdot 3 \%(\mathrm{w} / \mathrm{w})$ of the AIR.

The chromatographic behaviour on DEAE-Sephacel of the three $\mathrm{NaCl}$-soluble fractions are very similar (yields $85 \%$ to $95 \%$ in galacturonic acid; see Fig. 3). Very minor amounts of unbound material are found, $2.4 \%, 0.6 \%$ and $2.5 \%(\mathrm{w} / \mathrm{w})$ of the injected material for SP0 $\cdot 16$, SPO 5 and SP1, respectively. The bound material is eluted in two acidic populations which are partly resolved, and a higher neutral sugar content is found for the material eluted with $0.7 \mathrm{M}$ acetate buffer. These elutions pattern are related to those obtained for OXP and HP. The neutral sugar composition of these crude pectins is thought to be almost identical to that of the purified pectins because of the low content in the unbound material on the ion-exchange column. Their neutral sugar distribution is roughly similar to OXP, but degrees of methylesterification for the three fractions are lower than for OXP (see Table 2).

SP0 16, SP0 5 and SP1 have similar elution patterns on Sepharose 2BCL (yields $85 \%$ to $90 \%$ in galacturonic acid, see Fig. 4). More and more material is excluded from the gel as the ionic strength is increased. Except for the excluded material, the $M_{\mathrm{w}}$ distribution is similar to OXP as is the variation in the galacturonic acid/neutral sugar ratio with molecular weight (see Figs 2 and 4). The estimated $M_{\mathrm{v}}$ of SP0.5 (52600) is higher than that of OXP (40900) and is in good agreement with results obtained from the Sepharose $2 \mathrm{~B}-\mathrm{CL}$ experiments.

These results suggest that oxalate has a specific role, which may be the removal of the remaining calcium cations. Repartition of methoxyl groups along the galacturonan chains greatly influences the calcium binding capacities of pectins (Thibault \& Rinaudo, 1985), a blockwise distribution of methoxyl groups, previously reported in natural pectins (Tuerena et al., 1982), could explain the high degree of methylesterification of the OXP. Oxalate- and $\mathrm{NaCl}$-extracted pectins are not clearly 


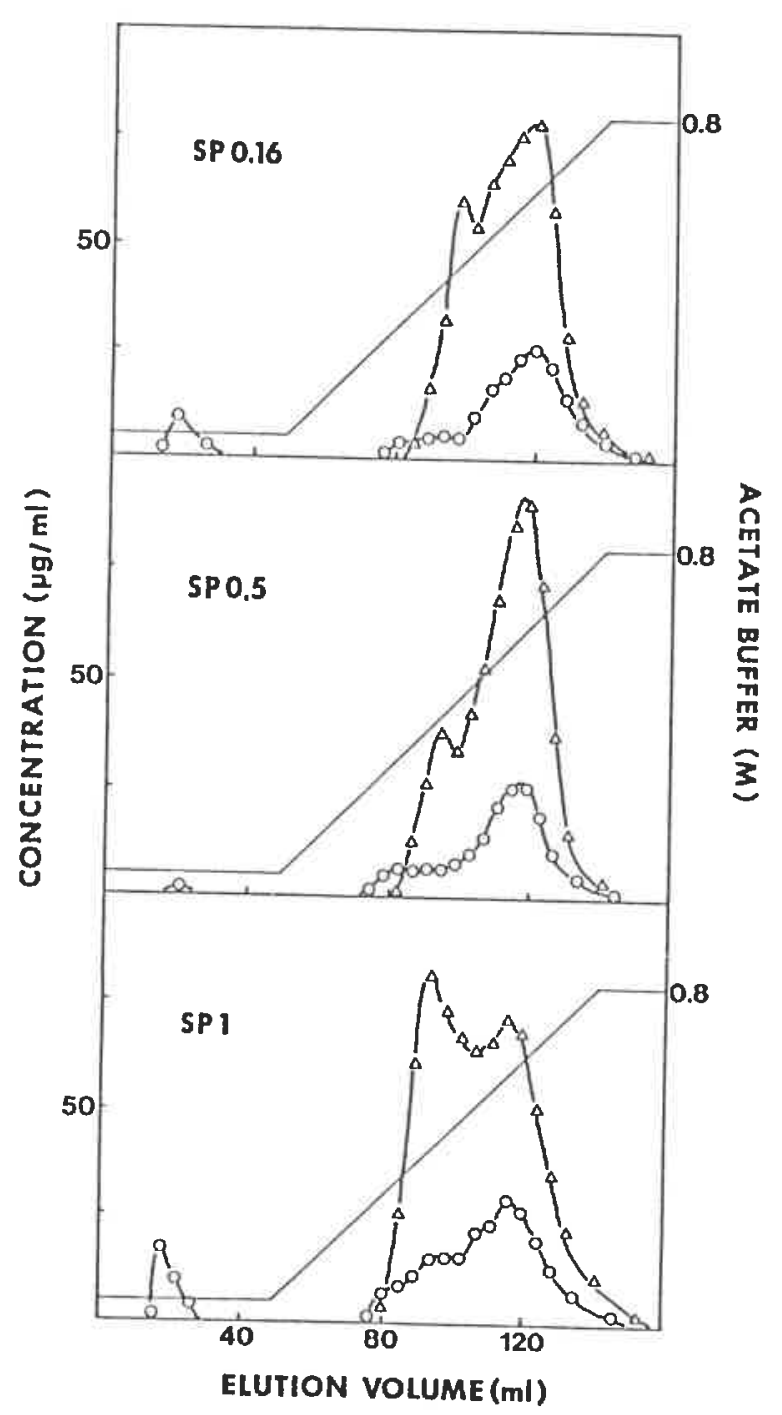

Fig. 3. Ion-exchange chromatography on DEAE-Sephacel of crude pectic substances from pulp of grape berries extracted at $20^{\circ} \mathrm{C}$ by $0.16 \mathrm{M} \mathrm{NaCl}$ (SP0.16), $0.5 \mathrm{M} \mathrm{NaCl}$ $(\mathrm{SP} 0.5)$ and $1 \mathrm{~m} \mathrm{NaCl}(\mathrm{SP} 1) .-\triangle-$ anhydrogalacturonic acid, - O- neutral sugars determined by $m$-phenylphenol and orcinol method, respectively. Chromatograms were recalculated for $2.5 \mathrm{mg}$ (SP0.16), $2.5 \mathrm{mg}$ (SP0.5) and $3.5 \mathrm{mg}$ (SP1) of injected AGA.

related, and the ability of $\mathrm{NaCl}$ solutions to remove pectic substances is not well understood. As uronic polymers become more flexible with increasing ionic strength (Jarvis, 1982), pectins could be released from cell walls if they are entangled mechanically. Substitution of calcium by sodium cations may also remove pectic polysaccharides to some extent. A combination of these two phenomena is probably involved and could explain the differences $\left(M_{\mathrm{v}}, \mathrm{DM}\right)$ and similarities (elution pattern on DEAE-Sephacel and Sepharose CL-2B, neutral sugar composition) of oxalate and $\mathrm{NaCl}$-extracted pectins. 


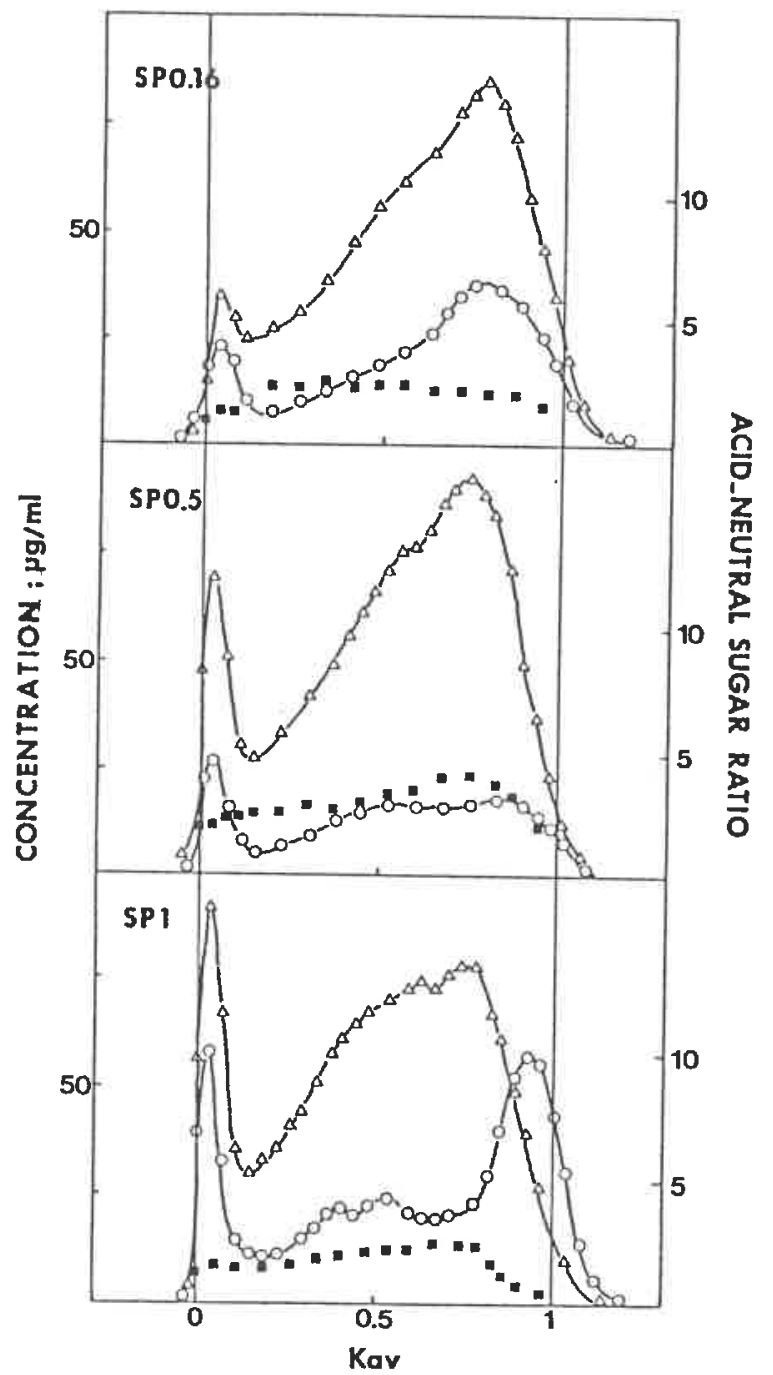

Fig. 4. Gel-permeation chromatography on Sepharose 2B-CL of crude pectic substances from pulp of grape berries extracted at $20^{\circ} \mathrm{C}$ by $0.16 \mathrm{M} \mathrm{NaCl}$ (SP0.16), $0.5 \mathrm{M}$ $\mathrm{NaCl}(\mathrm{SP} 0.5)$ and $1 \mathrm{~m} \mathrm{NaCl}(\mathrm{SP} 1) .-\Delta-$ anhydrogalacturonic acid, - O- neutral sugars determined by $m$-phenylphenol and orcinol method, respectively. $-m-$ acidic/ neutral sugars ratio. Chromatograms were recalculated for $6 \mathrm{mg}$ (SP0.16), $7 \mathrm{mg}$ (SP0.5) and $7 \mathrm{mg}$ (SP1) of injected AGA.

\section{CONCLUSION}

The pectic fractions obtained by the classical sequential extraction, scheme (I) were characterized, and emphasis was placed on the OXP fraction because of their high DM value. Attempts were made to provide explanations for the removal of pectic substances by $\mathrm{NaCl}$ solutions (sequential extraction II). However further investigations must be undertaken, using cations of different sizes and charge to understand the action of salts. 


\section{ACKNOWLEDGEMENT}

The authors wish to thank Dr J. M. Brillouet for helpful discussions during the preparation of the manuscript.

\section{REFERENCES}

Ahmed, A. E. R. \& Labavitch, J. M. (1977). J. Food Sci. 1, 361.

Albersheim, P. (1975). In Plant Carbohydrate Biochemistry, ed. J. B. Pridham, Academic Press, New York, pp. 145-64.

Aspinall, G. O. (1980). In The Biochemistry of Plants, ed. J. Preiss, vol. 3, Academic Press, New York, pp. 473-500.

Barbier, M. \& Thibault, J.-F. (1982). Phytochemistry 21, 111.

Blumenkrantz, N. \& Asboe-Hansen, G. (1973). Anal. Biochem. 54, 484.

De Vries, A. J., Voragen, A. G. J., Rombouts, F. M. \& Pilnik, W. (1981). Carbohydr. Polym. 1, 117.

De Vries, A. J., Rombouts, F. M., Voragen, A. G. J. \& Pilnik, W. (1984). Carbohydr. Polym. 4, 89.

Dey, P. M. \& Brinson, K. (1984). In Advances in Carbohydrate Chemistry and Biochemistry, vol. 42, eds S. Tipson \& D. Horton, Academic Press, New York, pp. 265-382.

Jarvis, M. C. (1982). Planta 154, 344.

Jarvis, M. C. (1984). Plant, Cell Environ. 7, 153.

Jouany, J. P. (1982). Sci. Aliment. 2, 131.

Kabawata, A. (1977). Memoirs of the Tokyo University of Agriculture, vol. XIX.

Knee, M. \& Bartley, I. M. (1981). In Recent Advances in the Biochemistry of Fruits and Vegetables, eds J. Friend and T. L. Rhodes, Academic Press, New York, pp. 133-48.

Lowry, O. H., Rosebrough, N. J., Farr, A. L. \& Randall, R. J. (1951). J. Biol. Chem. 193, 265.

Michel, F., Thibault, J.-F. \& Doublier, J.-L.(1981). Sci. Aliment. 1, 569.

Mourgues, J. (1979). Ann. Technol. Agric. 28, 121.

Mourgues, J. (1981). Sci. Aliment. 1, 377.

Mourgues, J. (1983). Thèse de docteur-ingénieur, Université Paul Sabatier, Toulouse.

Mourgues, J. \& Courtoisier, J. (1983). Conn. Vigne Vin 17, 269.

Owens, H. S., Lotzkar, H., Schultz, T. H. \& Maclay, W. D. (1946). J. Am. Chem. Soc. 68, 1628.

Peynaud, E. \& Ribereau-Gayon, P. (1971). In The Biochemistry of Fruits and their Products, ed. A. C. Hulme, vol. 2, Academic Press, New York, pp. $171-205$.

Pilnik, W. \& Voragen, A. G. J. (1970). In The Biochemistry of Fruits and their Products, ed. A. C. Hulme, vol. 1, Academic Press, New York, pp. 57-87.

Pilnik, W. \& Rombouts, F. M. (1985). Carbohydr. Res. 142, 93.

Potty, V. H. (1969). Anal. Biochem. 29, 535.

Robertson, G. L., Eschenbruch, R. \& Cresswell, K. J. (1980). Am. J. Enol. Vitic. 31, 162. 
Rombouts, F. M. \& Thibault, J.-F. (1986). Carbohydr. Res. 154, 177.

Rouau, X. \& Thibault, J.-F. (1984). Carbohydr. Polym. 4, 111.

Saeman, J. F., Moore, W. E., Mitchell, R. L. \& Millet, M. A. (1954). Tappi 37,

Selvendran, R. R. (1975). Phytochemistry 12, 1011.

Selvendran, R. R., March, J. F. \& Ring, S. J. (1979). Anal. Biochem. 96, 282.

Souty, M., Thibault, J.-F., Navarro-Garcia, G., Lopez-Roca, J. M. \& Breuils, L. (1981). Sci. Aliment. 1, 67.

Stevens, B. H. \& Selvendran, R. R. (1984). Carbohydr. Res. 125, 321.

Thibault, J.-F. (1979). Lebensm.-Wiss. u. Technol. 12, 247.

Thibault, J.-F. \& Rinaudo, M. (1985). Biopolymers 24, 2131.

Tollier, M. T. \& Robin, J. P. (1979). Ann. Technol. Agric. 28, 1.

Tuerena, C. E., Taylor, A. J. \& Mitchell, J. R. (1982). Carbohydr. Polym. 2, 193.

Usseglio-Tomasset, L. (1978). Ann. Technol. Agric. 27, 261.

Vidal-Valverde, A., Herrarez, J., Blanco, I. \& Rojas-Hidalgo, E. (1982). J. Food Sci. 47, 1840.

Wood, P. J. \& Siddiqui, I. R. (1971). Anal. Biochem. 39, 418. 